\title{
Ami Ayalon
}

\section{PRIVATE PUBLISHING IN THE NAHDA}

The Arab cultural-literary "awakening" of the late 19th century, known as the nahda, represented the first phase of mass printing in the Middle East, a historic development of major implications. Underlying new trends in social, political, and cultural thought, it entailed the large-scale production of printed texts, introduction of new diffusion channels, and emergence of broad reading audiences. The present study explores one facet of these dynamic changes: the advent of private publishing first centered in Egypt and Lebanon. Through the individual prism of Khalil Sarkis - a Beirut printer, publisher, bookseller, and author (1842-1915) - the article examines early book- and journal-publishing initiatives by printers, bookshop owners, and others, as well as their motivations and dilemmas. The emerging scene illustrates a vivid and rapid cultural shift, arguably a kind of "printing revolution" akin to that which had occurred in early modern Europe. 